\title{
The way towards food sustainability: some insights for pasta supply chain
}

\author{
Marisa Faggini ${ }^{1}$ (D) Silvia Cosimato ${ }^{2} \cdot$ Anna Parziale $^{3}$
}

Received: 24 June 2020 / Accepted: 17 September 2021

(C) The Author(s) 2021

\begin{abstract}
Over the last decades, circular economy and its implications for sustainability have gained momentum in several socio-economic domains (e.g., academia, industry, politics, society), even though the relationship between them remains poorly understood. This situation has blurred the conceptual definition of both terms, limiting their research and practice effectiveness. To counteract this situation, scholars and policymakers are approaching Circular Economy as able to inspire the development of sustainable development strategies and to increase the sustainability of the current economic system, balancing the need for economic development and the importance of protecting environmental resources and people wellbeing. Drawing on the previous considerations, this study aims to contribute to address this gap, better understanding how a circular economy approach can contribute to challenge the number of sustainability issues that currently affect supply chains. In doing so, the analysis has been focused on the investigation of a specific supply chain, the pasta supply chain. To this end, after a brief theoretical recognition, an interpretative model has been proposed for better recognizing and describing the enhancing actions that-at each supply chain's stages - can improve process efficiency, output effectiveness and, therefore, the overall sector sustainability. However, it is worth noting that the inherently theoretical nature of the study somewhat limits it; therefore, future empirical research is needed to further test the proposed model, applying it to other real applicative sets.
\end{abstract}

Keywords Sustainability $\cdot$ Sustainability transition $\cdot$ Food system · Pasta supply chain · Circular economy

JEL Classification Q01 · Q18

Marisa Faggini

mfaggini@unisa.it

Extended author information available on the last page of the article 


\section{Introduction}

Food sustainability is a major issue for these and for the years to come, because it is strictly related to undressed global environmental, social, and economic challenge (IPES-Food, 2015; Schott et al., 2016; Sonnino \& Coulson, 2021).

Due to the nature of its activities, food system remains mostly unsustainable both in environmental and social terms. In fact, for a long time the "productivist paradigm" dominated this system (Gaitán-Cremaschi et al., 2019), generating several negative outcomes mainly impacting on the environmental sphere of sustainability "such as land, water, and ecosystem degradation; biodiversity loss; excessive greenhouse gas emissions; persistent malnutrition and hunger and fail to eradicate poverty particularly of rural populations" (El Biali et al., 2019, p.5). However, it is worth noting that other negative outcomes affect food system, a great amount of waste and loss, produced alongside the whole supply chain (Seuring \& Müller, 2008; IPSES, 2016; Farooque et al., 2019).

Food waste and loss have a great influence on the ecological (un)sustainability of food system; thus, in European Union (EU), the International Panel of Experts on Sustainable Food Systems (IPES) ascertained that about the $20 \%$ of the produced food is wasted alongside the whole supply chain. This annually costs about 143 billion euros, including wasted resources and environmental impacts (IPES, 2016). In Italy, about 20 million tons of food is wasted every year, which costs about 12 billion euro per year (FUSIONS, 2016).

A possible response to the sustainability issues that affect the system under scrutiny comes from the ecological economics, "an interdisciplinary field focused on issues of sustainable development that have emerged in response to the difficulties in solving the global and local environmental problem" (Shmelev, 2016, p.32). Ecological economics offers an interesting framework for analysing and supporting the transition of different productive system towards sustainability, which has been considered as pointing to meet world population essential needs-such as hunger and poverty-maintaining at the same time the supporting systems and living resources fundamental for planet's life (National Research Council, 1999). Thus, "population numbers, location, and trends help define a sustainability transition by bounding both the numbers of humans whose needs are to be met and the size of the driving force of threats to the planet's life support systems" (Kates and Parris, 2003, p.8064).

Ecological economics - together with system theory, industrial ecology, regenerative design, performance economy, cradle to cradle, and biomimicry (Ellen MacArthur Foundation, 2013; Ghisellini et al., 2016; Winans et al., 2017)—is at the core of Circular Economy (CE), which offers "tools to enhance and optimize for sustainability within the Western food system" (Jurgilevich et al., 2016, p.2). It follows that the implementation of CE strategies can contribute to make resources' use more efficient and effective at all the stage of a supply chain (Borrello et al., 2017; Sousa-Zomer et al., 2018), also counteracting waste and loss occurring from production to retail and even to consume (Alamar et al., 2018; Richards \& Hamilton, 2018). In doing so a step forward the transition toward 
sustainability - a future-oriented process that Sorman and Giampietro (2013) considered non-voluntary, and which needs to be forced and directed by international and national institutions - can be taken also enacting CE strategies (BuchHansen, 2018). In this sense, it is worth noting that the literature on circular economy strategy for food system sustainability is still in its infancy (Batista et al., 2018; De Angelis et al., 2018; Howard et al., 2019; Liu et al., 2018).Therefore, this study aims at contributing to bridge this gap further investigating the potential of CE strategies in supporting the transition of food supply chains towards sustainability (Genovese et al., 2017).

A general, simple, but essential question inspired this work, the enactment of CE strategies can contribute to make food industry and its supply chains sustainable? If yes, how? To address this question, the analysis has been focused on pasta industry and its supply chains, which represents one of the main subsectors of the food industry. In fact, for example Italian pasta industry annually produces about 3.4 million tons of pasta, which accounts for $6 \%$ of total national food industry production (IPO, 2014). For the purpose of the analysis, a specific framework developed by Giampietro (2019) has been implemented and further exploited. Thus, it offers a good support for approaching in an integrated way most of food and pasta systems' challenges, such as the progressive reduction and elimination of waste and loss.

The reminder of the paper is organized as follows. Section 2 delves on general revision of the theoretical background of food and pasta supply chain sustainability, focusing on the potential of circular economy strategy for the transition of food system towards sustainability. Section 3 presents and discusses the proposed interpretative model, while Sect. 4 argues some managerial and policy implications. Finally, Sect. 4.1 is dedicated to final remarks and further research lines.

\section{Theoretical background}

\subsection{Circular strategies and the transition of food sector towards sustainability: a focus on waste and loss}

Food system sustainability is one of the main and more pressing challenge of the modern society; thus, "food production strongly relies on environmental resources and services, and releases outputs into the environment. This implies that foodrelated activities can create negative externalities" (Banterle et al., 2018, p.59). Due to the afore-mentioned issues, food system sustainability has risen on the global governance agenda as well as on the current scientific debate, making policy-makers, scholars and practitioners engaged with the search for new approaches able to counteract this system intrinsic unsustainability and to meet socio-economic goals, such as the environmental protection, a better social welfare as well as food security (IPES-Food, 2016; Caron et al., 2018; Béné et al., 2019). These goals are at the core of the so-called transition toward sustainability, which National Research Council (1999) considered as the ability in responsibly use both natural and human resources simultaneously to "meet the needs of a much larger but stabilizing human population, (...) sustain the life support systems of the planet, and (...) substantially 
reduce hunger and poverty" (p.5). This transition should be based on the disposition to link ecological integrity, societal viability and intergenerational justice (Luederitz et al., 2017), going beyond the traditional developmental policies, promoting a viable growth, possible enhancing well-being and social equality inspired by a qualitative approach to the development (getting better) rather than a quantitative approach (getting bigger) (Giampietro, 2019; Rees, 2020). This offers a good support for food system, considering most of its challenges (e.g., the progressive reduction and elimination of waste and loss, etc.) in an integrated way. Due the fact that the global food sustainability is essential to the survival and wellbeing of human being, at the macro-level this implies the development and the enactment of international and national policies, while at micro-level, the implementation of specific operative strategies, pointing to reduce the negative externalities of supply chains (Jellil et al., 2018). These actions can highly support socio-economic actors (mainly individuals and companies) in approaching food production, selling, and consumption in a more responsible way, understanding the importance of a sustainable culture for fighting the unsustainability of food system (Nasir et al., 2014). It is worth noting that this work is mainly intended at better investigating the strategies implemented at microlevel to boost food system sustainability and its related business process.

The existing link between $\mathrm{CE}$ and sustainability is mainly due to the fact that $\mathrm{CE}$ strategies and the related practice are often implemented to boost sustainable development, mitigating — at the same time - the issues related to critical material supply and in doing so making industrial systems more sustainable (Kravchenko et al., 2019). In fact, these strategies can support the harmonic achievement of the desired social, economic and environmental goals (Elia et al., 2017), for example reducing resource consumption, minimizing waste production, and boosting profitability.

Applied to food system, circular economy (CE) strategies can support its transition towards sustainability, enacting specific enhancing practices, pointing for example to reduce food loss and waste and to support companies to keep "products, components, and materials at their highest utility and value at all times in both biological and technical cycles" (Farooque et al., 2019, p.884). It follows that biological ingredients or nutrients can be safely returned to the biosphere, enhancing natural capital and at the same time contributing to the economy with minimal wastages (EMF, 2012, 2014). Therefore, a CE approach to food supply chains implies, for example, the disposition to reuse organic scraps as input of new and sometimes different production processes to obtain brand new outputs (e.g., fertilizers, animal feed, other human food, textile fibers, cosmetics, herbals and even fuel) (Clark et al., 2012; Toldrà et al., 2012; Lin et al., 2013; San Martin et al., 2016; Borrello et al., 2017).

Even though, the implementation of CE strategies to the management of food supply chain is still in its infancy, Jurgilevich et al. (2016) proposed some possible applications, pointing to minimize food loss and progressively eliminate waste, considering them as valuable resources (e.g. second raw materials) that can be used as input of the same (closed loop) or different (open loop) supply chain (Weetman, 2016) (See Fig. 1). This is mainly due to the essential processes at the core of CE strategies, recycling, retaining, reusing, repairing, remanufacturing, refurbishing and/or recovering, which are directed to the 'revitalize' waste, scraps, used materials and goods (Farooque et al., 2019; Genovese et al., 2017). 
Fig. 1 Food supply chain goes circular. Source: Adapted from Farooque et al., (2019)

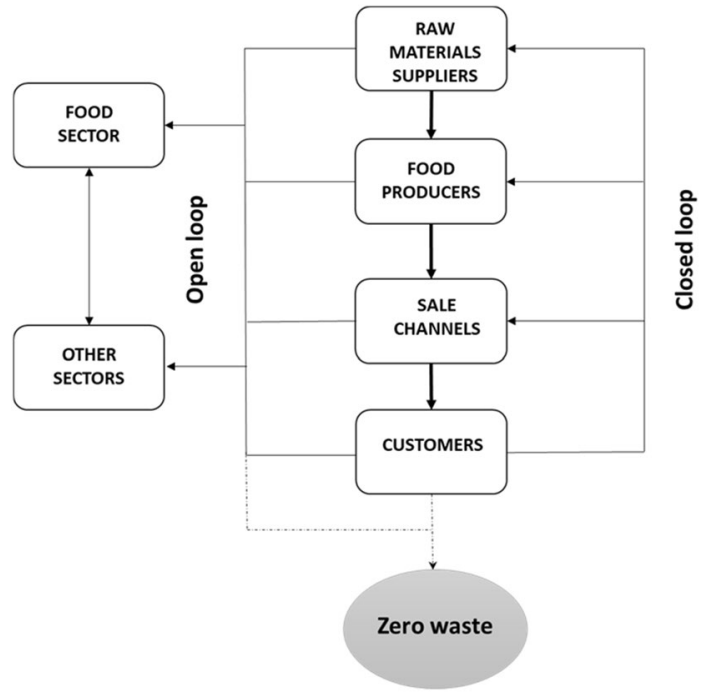

Drawing on food loss and waste and their importance for taking a step forward sustainability, it is worth noting that literature often considers them at some extent synonymous, just because they are both related to food system efficiency. However, it is worth noting that these two concepts are quite different; thus, food loss occurs upstream in the supply chain, while waste mostly occurs downstream the supply chain, mainly at the retail and consumption stages (Alamar et al., 2018). A punctual definition of the two concepts comes from FAO (The Food and Agriculture Organization of the United Nations), which considers loss as food's quantity or quality decrease, and waste as the removal of food that fits for consumption or expired from supply chain, due to economic behavior, poor stock management, or neglect (FAO, 2014). More in details, on the one hand food waste is currently considered a worldwide problem, which environmental (UNEP, 2014), economic (Garrone et al., 2014), and social (Evans, 2011) influence calls for new national and international policies (WRAP, 2013, 2017; IFPRI, 2016; Searchinger et al., 2019). In this sense, the United Nation's Food and Agriculture Organization (FAO) underlined that the inefficiencies of food system (waste and loss) annually cost about a trillion dollars per year or two trillion dollars when social and environmental costs are considered (FAO, 2013). On the other, food loss are all those edible parts of food, produced at each stage of the supply chain (Shafiee-Jood \& Cai, 2016), which get lost at harvest, processing and transportation stage or which are not consumed (e.g., expired, served but not consumed, etc.) (Galli et al., 2017). In a similar vein, the Agenda 2030 with its Sustainable Development Goals (SDGs) approached food system sustainability, declaring (in the 12.3 SDG) that s "by 2030, halve per capita global food waste at the retail and consumer levels and reduce food losses along production and supply chains, including post-harvest losses" (United Nations General Assembly, 2015, p. 27). 
To minimize the negative influence of loss and waste, food system could redesign of its value chains (Duru et al., 2015) according to CE perspective (Brennan et al., 2015; Jurgilevich et al., 2016), defined as "restorative by design, and which aims to keep products, components and materials at their highest utility and value, at all times" (Webster, 2015, p.16).

\subsection{Pasta supply chain sustainability: how to improve it}

Pasta production represents the core activity of one of the most important sub-systems of the food system, which globally amounts to about 14.3 million metric tons, with about the $22 \%$ produced in Italy (UNAFPA, 2015). It is worth noting that Italy is both the main pasta producer and consumer; thus, it has the worldwide maximum consumption pro capita (about $23.5 \mathrm{~kg}$ per year), follows Tunisia (16 kg year.) and Venezuela (12 kg year.) (UNAFPA, 2015).

This numbers also open to some environmental problems; thus, the impact of this sector on the environment is high, and it has pushed its companies to start to implement some different methods to measure their activities footprint (e.g., Life Cycle Assessment, Environmental Product Declaration, International Organization for Standardization or ISO standards etc.) and to consequently, improve the sustainability of their production (Recchia et al., 2019). In doing so, pasta manufacturing companies have started to rethink the organization of their supply chains as well as the materials (chemicals or not) used during the productive steps, which are currently rise to an unsustainable level for environment (Cappelli \& Cini, 2021).

Pasta industry and its supply chains' sustainability also suffer for the high rate of loss and waste; in fact, for example in European and North American countries, pasta loss and waste accounts for about the $35 \%$ of the total production, most of them occurring at the processing and consumption stages (Gustavsson et al., 2011). To counteract these phenomena, the Food Loss and Waste Accounting and Reporting Standard (FLW Standard) provided "requirements and guidance for quantifying and reporting on the weight of food and/or associated inedible parts removed from the food supply chain" (Hanson's et al. 2016, p. 11).

This standard has been used to detect the materials removed (waste) from or lost (loss) at each stage (see Fig. 2) of the supply chain in order to define some correction actions pointing to reduce or even eliminate them, also choosing possible future destinations and/or use for loss and waste (Principato et al., 2019). Follows a brief description of enhancing actions implemented at all the stages of pasta supply chain.

Even though at production stage, loss is limited (e.g., straws and field losses), it could be further reduced using scraps as input of other supply chains such as animal feed production, cosmetics and herbal production or even energy production. At the pre-milling stage, dedicated to "wheat debranning" or to the progressive removal of grain external layers, the scrap fraction can be used for producing animal feed (Cimini et al., 2019), while some wheat dockage fractions, and bran particles can be converted into wheat feed pellets (UNAFPA, 2015). It has to be noted that the most of loss and waste occur during pasta production, when the semolina obtained from the milling is sent to the production unit. The related scraps and/or the wrong 


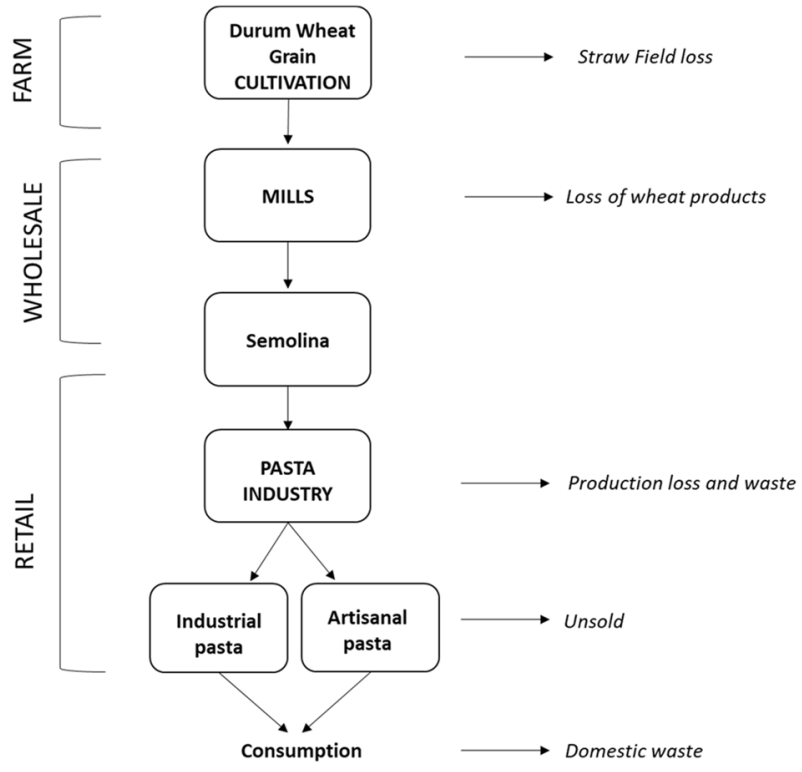

Fig. 2 Pasta supply chain, a focus on loss and waste. Source: adapted from Ricci et al., (2019)

formats can be used as animal feed, composting or-on some occasions-sent to food banks as human food.

At the retail stage, the most of loss and waste-which amount to $1 \%$ of the packed pasta - are due to package damage and breakage, which even though do not allow pasta selling as human food (UNAFPA, 2018), make it saleable as animal food, while just a minimum part of it could be sent, for example, to food banks (Principato et al., 2019).

Finally, at the consumption stage, if losses are near to zero, waste comes from peculiar consumer behaviors and habits (e.g., food not used in time, personal preferences, leftover waste, the growing number of families with just one or two members, etc.) (WRAP, 2013; Cicatello et al., 2016). It is worth noting that at this stage, waste production is mostly due to wrong habits; thus, more than the $12 \%$ of cooked pasta get wasted for different reasons (e.g., because not used in time, excessive portions, etc.) (Principato et al., 2015; Mondéjar-Jiménez et al., 2016) and usually discharged as urban solid waste. Focusing on Italy, in 2016 the $26 \%$ of cooked pasta waste went to landfill, the $20 \%$ was incinerated and the remaining $52 \%$ composted or recycled (Last Minute Market, 2016).

If on the one hand, to change this situation-occurring at the production stageinternational and national institutions should promote educative and literacy initiatives, on the other at the remaining stages of the pasta supply chain, sustainability can be boosted enacting specific CE strategies. Recently, these latter are even more based on the potential of technological innovations, which often assume the form of the so-called "green" innovation, able to offer an ecofriendly management and treatment of raw materials, transformative and distributive processes (Cappelli \& Cini, 
Fig. 3 Pasta supply chain goes circular. Source: Adapted from Farooque et al., (2019)

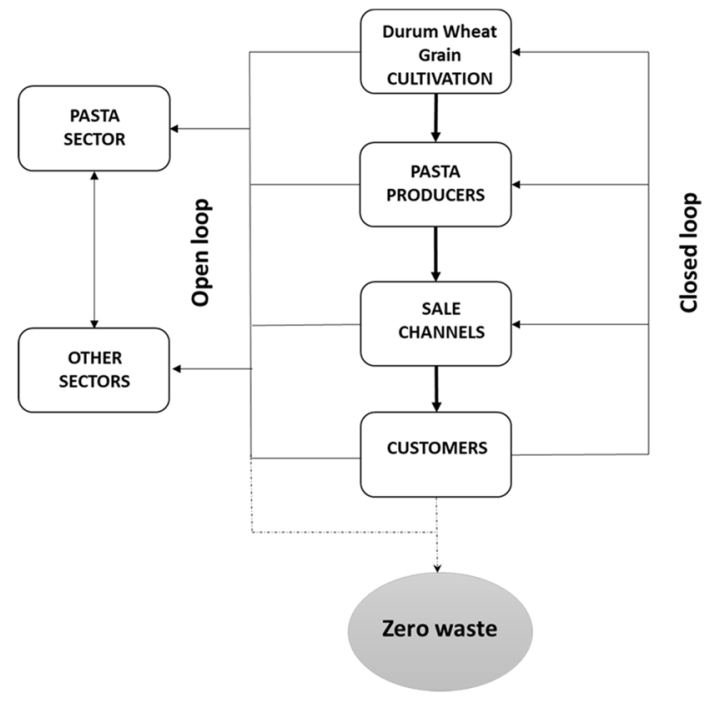

2021). It follows that innovations act as a transformative driver, able to inspire the development and the enactment of CE strategies intended at improving efficiency, effectiveness and sustainability of the whole pasta supply chain (Cappelli et al., 2020).

\section{CE strategies for making pasta supply chain more sustainable: the proposed approach}

Taking the above background (see Sects. 2 and 2.1), this work aims at contributing to the research on the transition towards sustainability of the food system, analyzing the effects that the enactment of CE strategies can have on the sustainability the specific sub-sector of the pasta production. To this end, a holistic approach, pointing to merge efficiency, effectiveness and sustainability (Barile et al., 2014), has been embraced. These three elements are essential for assessing the performance of human endeavor, but at the same time they represent a triple target that systems have to meet for the purpose of surviving, also changing or innovating their configuration as well as the way their actors mutually interact (Barile et al., 2014; Faggini et al., 2019). In this sense, the activation of CE strategies (Fig. 2) can contribute to pasta supply chain efficiency and effectiveness minimizing the impact of materials removed from the pasta supply chain, which are no more discharged, but used to start new production processes as secondary raw materials (Mihai \& Ingrao, 2018; Valenti et al., 2018) (Fig. 3).

This implies that all processes occurring at each stage of the pasta supply chain should be holistically and harmonically managed, in order to enact specific strategies able to improve processes' efficiency (or doing things in the right way), their outputs' effectiveness (or the right things that must be done) and the overall supply 


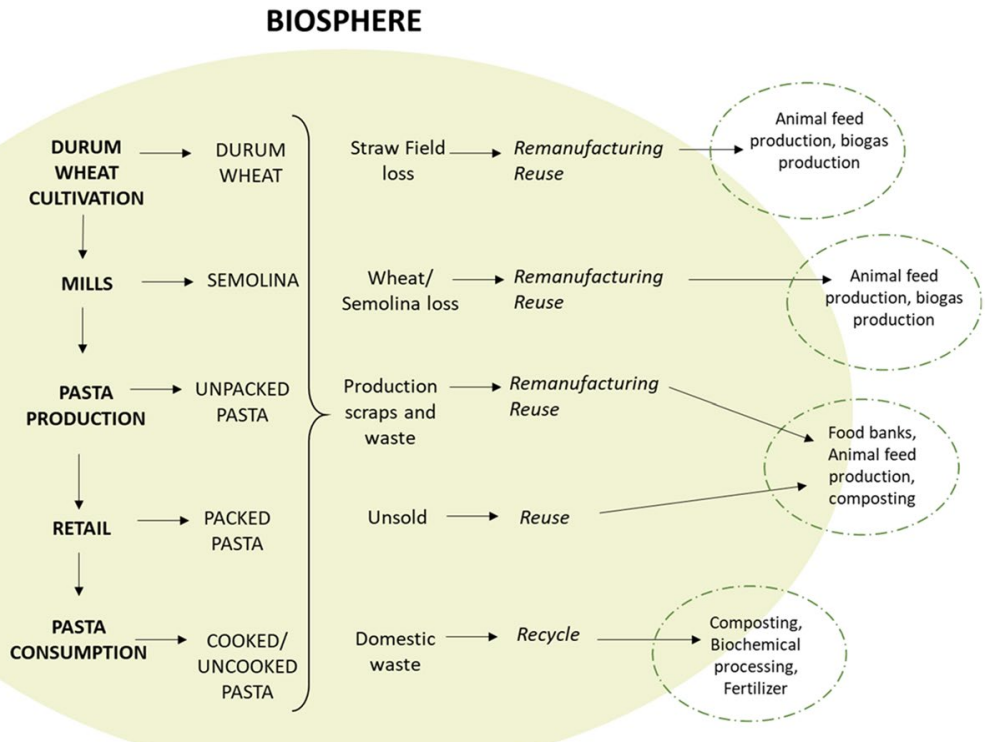

Fig. 4 A possible configuration of a circular pasta supply. Source: Adapted from the Ellen MacArthur Foundation, 2014

chain sustainability (or the effort towards the establishment of the right relationships with other systems) (Spohrer et al., 2007) (Fig. 4). Follows the presentation and discussion of some possible CE strategies that can contribute to the afore-mentioned harmonization.

\subsection{Process efficiency}

Efficiency has been technically defined as the measure of how-at the production stage - a job or a task is carried out in terms of speed, fastness, doing things right, hardworking, least wastage, high returns and similar. Therefore, it represents a concrete concept, easy to quantify and to understand, because its applications are characterized by space and time limitations.

In the pasta supply chain, loss mainly inhibits processes' efficiency; thus, companies are trying to solve this problem implementing specific technologies designed for being used both upstream and downstream the supply chain, without harming the environment. In particular, several innovative and smart technologies have been recently introduced for having high quality durum wheat, for example specific cultivation monitoring systems and advanced harvesting methods (Barret et al., 2012). These technologies are often based on drones, which ensure a constant field monitoring as well as an algorithm-based data recording and processing systems that provide information about possible parasites attacks, time of maturation, gas measurement and/or liquid spraying (e.g., fertilizers, plant growth regulators, etc.) (Mogili 
\& Deepak, 2018; Murugan et al., 2017). This has also led to the development of the so-called precision agriculture (Cassman, 1999; Gebbers \& Adamchuk, 2010; Mahlein, 2016), based on spatial diagnostics of crops and soils, which are also at the core of the emergent information-based agricultural management systems (or smart agriculture) (Lipper et al., 2014; Taylor, 2018).

In terms of production and storage, several technologies have been implemented to enhance the efficiency of these processes, mostly intended to remove impurities (pre and post melting) and to monitoring storage conditions (e.g., temperature, time, cleanness, insects and parasites presence, etc.) (Gaustad, 2018).

Advanced technologies and alternative transportation systems are contributing to enhance the efficiency of the processes occurring during the retail phase (see Fig. 3). In particular, the optimization of transportation and the implementation of specific logistics management systems (e.g., first-expired-first-out transportation model) have minimized the most frequent pasta losses due to package damages, which make it no more edible (Jedermann et al., 2014). Specific technology-based packaging solutions have been also developed to extend packed pasta self-life (or percentage of shelf-life available to consumers) (Smithers, 2016; Kirtil et al., 2017). Moreover, specific mobile apps have been also developed and implemented to better manage food stores (WRAP, 2014), preserving pasta quality and optimizing its use before the expiring date (Woolley et al., 2016).

At the latest stage of the pasta supply chain (consumption), processes' efficiency is strictly related to the reduction of food waste coming from unsustainable consumer behavior. To counteract this situation, a change of consumer behavior should be further promoted (Principato et al., 2015), for examples through specific institutional initiatives intended to educate people to optimize their purchase (e.g., limiting over-purchasing, enhancing the management and the conditions of stored food, etc.) and cooking habits (e.g., avoiding over-preparation or over-serving) (Cicatello et al., 2016) as well as to enhance people disposition towards recycling (Fig. 5).

\subsection{Output effectiveness}

Output's effectiveness calls for a different approach to processes or for doing the right things in order to boost the quality of output (Nayak, 2014). When related to the pasta supply chain, output effectiveness is mainly related to pasta safety and security (Nocella \& Kennedy, 2012).

For this specific sub-sector, the search for effectiveness is a quite new issue; thus, until recently it was rather efficiency-oriented or pointing to improve the production at lower costs. It follows that the related supply chains tend to remain based on traditional methods, such as the massive use of fertilizers, agricultural equipment or pesticides (Glazko \& Kosovski, 2018). Even though these methods have become obsolete, being no more in line with the current policies and programs pointing to boost the use of environmental-friendly materials and processes as well as to produce safe and secure food, which will not cause any harm to people during preparation and consumption (WHO, 2015). To achieve this goal, pasta should be protected from the physical, chemical and biological contamination that can occur during each 
BIOSPHERE

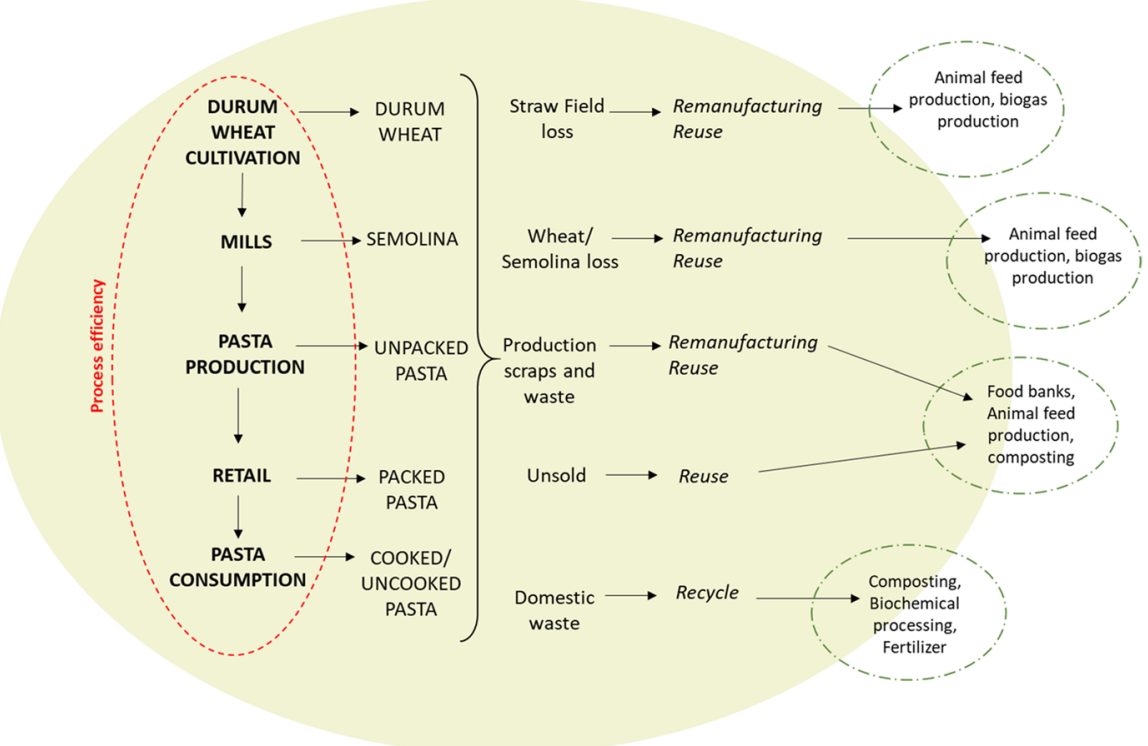

Fig. 5 Processes efficiency in a circular pasta supply chain. Source: Adapted from the Ellen MacArthur Foundation

phase of its supply chain (Bajpai et al., 2018). Due to the labour-intensive, timeand cost-consuming nature of conventional solutions, more effective solutions have come from nano technologies, which can ensure growing safety, security and even nutraceutical value to food, extending its shelf-life and reducing packaging waste (Duncan, 2011; He \& Hwang, 2016) (see Fig. 4). In particular, nanoparticles, carbon nanotubes, quantum dots and other active nano materials have been used to develop specific biosensors, intended to test food safety, monitoring its conservation state and proposing possible variations to the related environmental conditions (e.g., emperature, position on the shelves, etc.) (Carbone et al., 2016; Hoseinnejad et al., 2018). The packaging is one of the most critical elements of pasta safety, being currently permeable to natural substances, atmospheric gases and water vapours. Therefore, recently nano biocomposites have been used to improve it, developing gas barriers and biodegradable polymers reinforced with nano-fillers (Duncan, 2011; Youssef \& El-Sayed, 2018). Moreover, to ensure food and pasta safety several laws has been worldwide enacted. In particular, the European Food Safety Authority (EFSA) defined the maximum acceptable quantity of certain toxins for different products, such as the overall MPL of OTA ${ }^{1}$ is $5 \mathrm{~g} / \mathrm{kg}$ in cereals, $3 \mathrm{~g} / \mathrm{kg}$ in cerealderived products, and 5,10 , and $15 \mathrm{~g} / \mathrm{kg}$ in coffee, dried fruits, and spices respectively (EC Regulation No. 123/2005) (Fig. 6).

\footnotetext{
${ }^{1}$ This quantity refers to the maximum permitted levels (MPL) of Ochratoxin A (OTA), a mycotoxin produced by several fungi of the genera of Aspergillus and Penicillium.
} 


\section{BIOSPHERE}

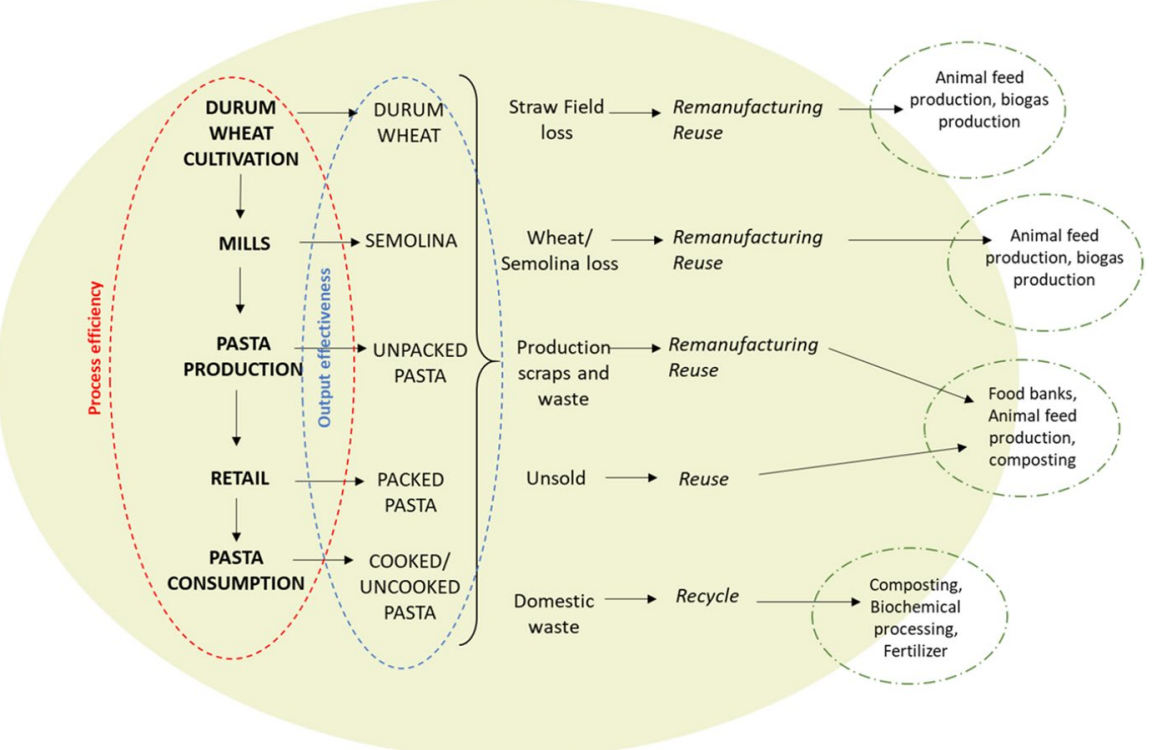

Fig. 6 Output effectiveness in a circular pasta supply chain. Source: Adapted from the Ellen MacArthur Foundation

\subsection{Sustainability}

Approaching processes' efficiency and output effectiveness in a more holistic way, some scholars considered sustainability able to offer to individuals and socio-economic organizations (often intended as systems) much more opportunity to survive (Saviano et al., 2019). In this sense, CE strategies represent a useful tool to support this harmonization.

Focusing on pasta supply chain, the implementation of these strategies can enhance its transition towards sustainability, exploiting collaborative interactions among the different supply chain actors as well as among different, but interrelated individuals, organizations and/or systems (Fig. 7).

The need for make pasta supply chain more sustainable led managers to pay growing attention not only to process efficiency and output effectiveness, but also to ethical issues, which-together with human well-being-can inspire alternative productive, managerial and commercial solutions (Galli et al., 2015), based for example on fair trade practices, product certification and alternative food networks (Goodman et al., 2012). To this end, more collaborative relationships among institutions, companies and people are needed (Barile \& Polese, 2010) in order to add long-lasting viability to this supply chain, to the whole food industry and in the long run to the whole society (Barile et al., 2013). Focusing on pasta supply chain, collaborative relationships between consumers, pasta producers and other industries operators seems essential to commit them to the transition towards more sustainable habits, processes and practices able to contribute to environmental maintenance, 


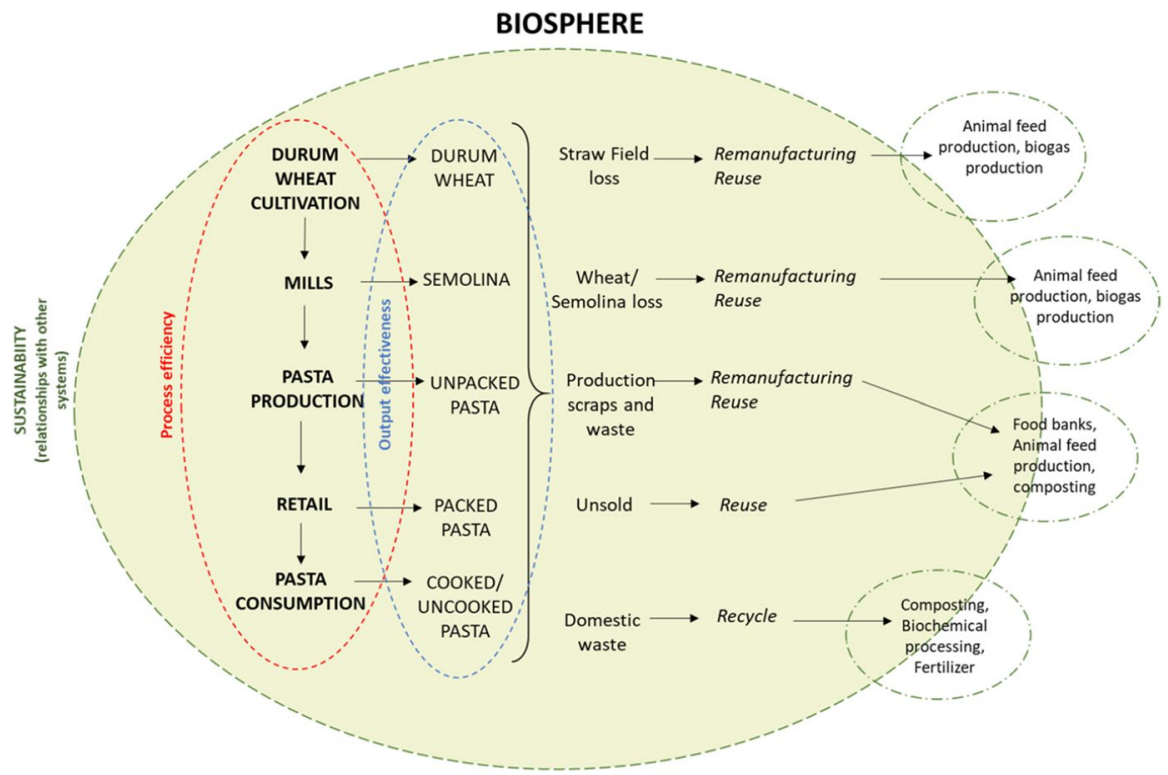

Fig. 7 The transition of circular pasta supply chain towards sustainability. Source: Adapted from the Ellen MacArthur Foundation

human wellbeing and economic prosperity for present and future generations (Borrello et al., 2016; Menozzi et al., 2015).

\section{Some managerial and policy implications}

The transition of the whole food system towards sustainability can be supported both by the implementation of new managerial approaches, especially based on circular strategies of supply chain management, and by social changes, "actively created, (re)produced and refined by several social groups as firms, universities and knowledge institutes, public authorities, public interest groups and users" (Geels, 2005, p.450). This implies the need for more holistic approaches, able to go beyond the mere supply and economic performance, "to encompass broader societal goals such as environmental protection, social welfare, and food and nutrition security" (Gaitán-Cremaschi et al., 2020, p.134). To meet these goals food system functioning should be based on new managerial strategies as well as on "more coercive rule structure, for example, the way food is produced and consumed" (Kuokkanen et al., 2018, p.1533).

Focusing on managerial perspective, the assumption of a CE approach to supply chain management implies the development of both closed-loop supply chain, where products or material return to the original producers, reducing or if possible, avoiding waste production (Kenné et al., 2012). However, as stated in the previous section, a $\mathrm{CE}$ approach to supply chain management can contributes to waste minimization and 
progressive elimination not returning used products to original producers but directing them to outsider firms that recover/reuse them (Ene \& Öztürk, 2014). Therefore, managers can boost pasta supply chain overall transition towards sustainability, exploiting socio-economic and environmental development through specific actions pointing to boost actors (e.g., producers, retailers, consumers, etc.) commitment towards more sustainable behaviors (González-Rodríguez et al., 2015). This implies that the engagement of all actors-both upstream and downstream the pasta supply chain-should be encouraged through specific enhancement and educational projects developed and promoted both by institutions and companies (Garcia-Garcia et al., 2017; Rueda et al., 2017). Moreover, this renewed approach to SCM can inspire managers towards a breakthrough performance, based on the achievement of process efficiency, output effectiveness and profitability that pave the way for the transition towards sustainability, minimizing at the same time the possible negative environmental, social and economic impacts.

Focusing on policy-makers' perspective, a first step could be the enactment and the promotion of specific laws and regulations as well as circular economy strategies (Geels et al., 2016; Grin et al., 2010; Shove, 2014), able to involve into collaborative relationships people, companies, scientific organizations and governments. In this vein, awareness campaigns promoted by institutions can highly contribute to change consumer behaviours, making dietary choices much more environmentally and socially sensitive (Schösler et al., 2015; Smith et al., 2016); thus, well-informed consumers "tend to make healthier and more sustainable decisions already that pay attention to labels and are influenced by information campaigns" (Jurgilevich et al., 2016, p.72). It follows that even though several people consider dietary choices a private matter, non-mandatory learning and education recommendations or initiatives should trigger the shift toward more aware and sustainable food consumption paths (Schösler et al., 2012). In a similar vein, also the action of universities, research centers and other scientific organizations seems to be also essential; thus, they are able to support the pasta supply chain actors through new technological and/or organizational solutions that add sustainability to the whole supply chain (Haas et al., 2015; Priefer et al., 2016). This is possible also thanks to the implementation of smart agriculture solutions and technologies (Azam et al., 2016; Gondchawar \& Kawitkar, 2016; Taylor, 2018), which are designed for improving the efficiency and effectiveness of pasta supply chain (Patil \& Kale, 2016). It follows that the assumption of a CE approach to the management of pasta supply chain would also contribute to the emergence of further and new opportunities for local/national development, befitting both stakeholders and the environment, reducing the environmental impact and, in so doing, creating new opportunities for socio-economic development (Secondi et al., 2019). Follows a brief summary of some possible policies and actions that can inform circular economy strategies for the transition of the pasta supply chain towards sustainability (see Table1).

\subsection{Final remarks}

This paper has explored the influence that the implementation of CE strategies can have on pasta supply chain and on its general transition towards sustainability. To 


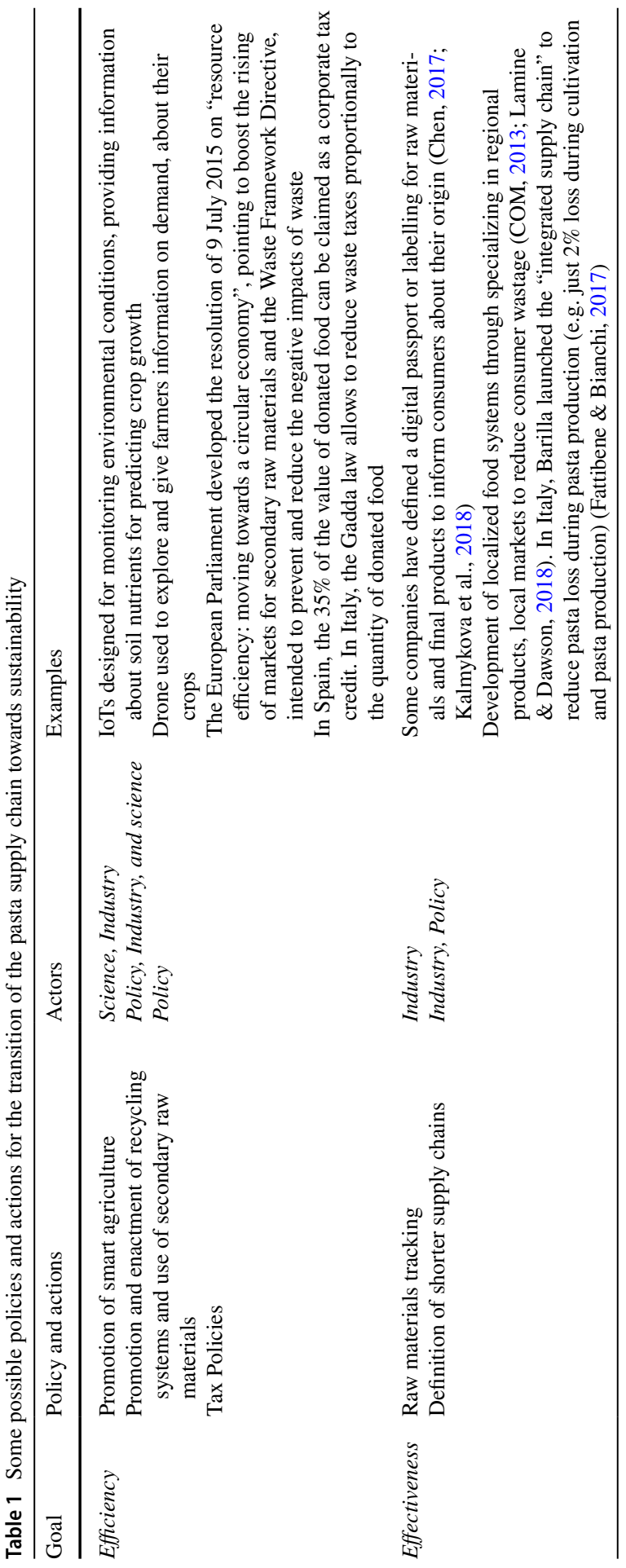




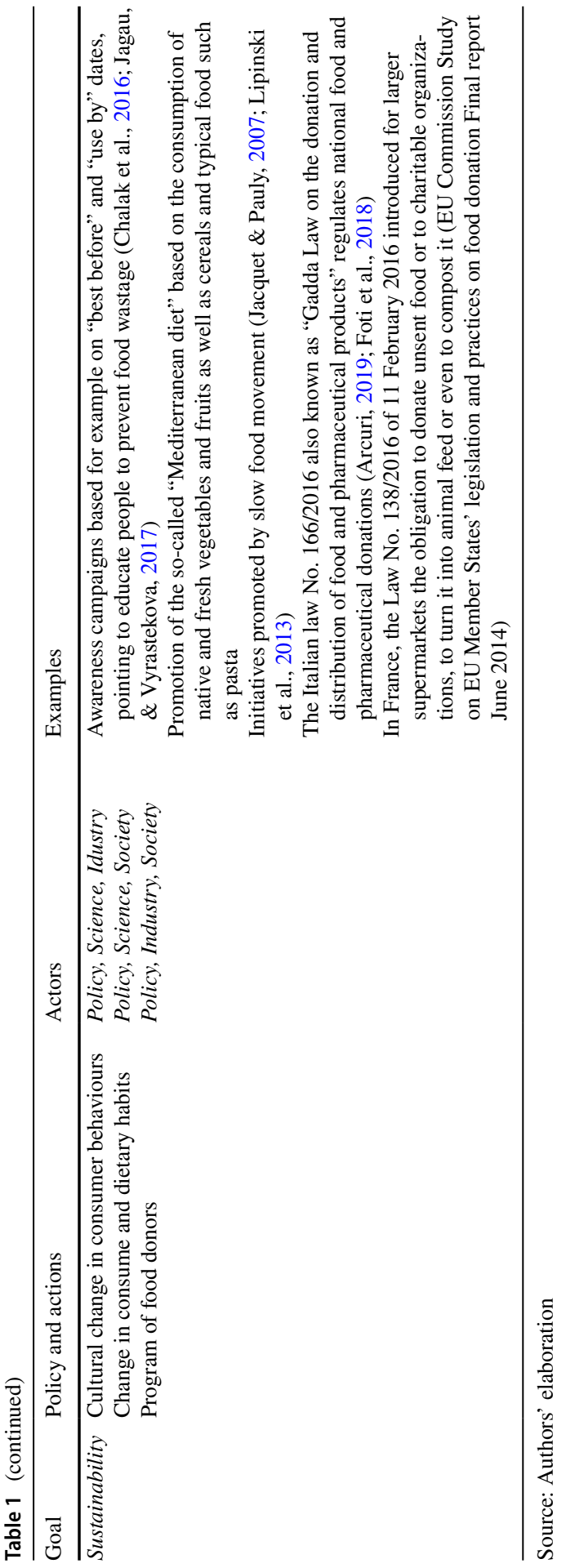


this end, some possible actions-which can be implemented both into the food system and into the pasta sub-system-have been identified and described. These strategies seem to be able to boost, at the same time, the efficiency (loss reduction), the effectiveness (waste reduction as well as the activation of recycle, reuse, regeneration and remanufacturing processes) and, therefore, the overall sustainability of the system under scrutiny. In doing so, this work has sought to provide supply chain managers with a range of strategic circular options and opportunities for taking a step forwards sustainability (Brennan et al., 2015; Jurgilevich et al., 2016). In this vein, some CE strategies have been identified, to challenge one of the most complex issue that affect this system, waste and loss minimization and complete elimination. To solve this problem a contribution comes not only from innovative and eco-friendly strategies of supply chain management, but also from technological innovation, and from institutional initiatives and actions pointing to change consumer behavior. This need for a general and global mind-set change (Giampietro \& Funtowicz, 2020), driven by the awareness of resources' scarcity, the willingness to reduce the environmental impact of production processes as well as a concrete change in both in production and consume processes (Murray et al., 2017; Tukker, 2015;). However, it is worth noting that a change like this can occur just when all the system actors are engaged with collaborative interactions (Barile \& Polese, 2010; Gaustad et al., 2018), pointing to challenge and change the unsustainability factors that still affect the pasta supply chain. Thus, some possible paths towards processes efficiency (e.g., loss and waste minimization through recycling and reusing programs), output effectiveness (e.g. outputs' quality and security enhancement) and the sustainability of the whole pasta supply chain have been presented and discussed. Even though this study offers interesting insights about the pasta supply chain transition towards sustainability, future empirical investigations are still needed in order to further test the proposed model, applying it to other specific settings.

Funding Open access funding provided by Università degli Studi di Salerno within the CRUI-CARE Agreement.

Open Access This article is licensed under a Creative Commons Attribution 4.0 International License, which permits use, sharing, adaptation, distribution and reproduction in any medium or format, as long as you give appropriate credit to the original author(s) and the source, provide a link to the Creative Commons licence, and indicate if changes were made. The images or other third party material in this article are included in the article's Creative Commons licence, unless indicated otherwise in a credit line to the material. If material is not included in the article's Creative Commons licence and your intended use is not permitted by statutory regulation or exceeds the permitted use, you will need to obtain permission directly from the copyright holder. To view a copy of this licence, visit http://creativecommons.org/licen ses/by/4.0/.

\section{References}

Alamar, M. D. C., Falagán, N., Aktas, E., \& Terry, L. A. (2018). Minimising food waste: A call for multidisciplinary research. Journal of the Science of Food and Agriculture, 98(1), 8-11. 
Arcuri, S. (2019). Food poverty, food waste and the consensus frame on charitable food redistribution in Italy. Agriculture and Human Values, 36(2), 263-275.

Azam, C., Le Viol, I., Julien, J. F., Bas, Y., \& Kerbiriou, C. (2016). Disentangling the relative effect of light pollution, impervious surfaces and intensive agriculture on bat activity with a national-scale monitoring program. Landscape Ecology, 31(10), 2471-2483.

Bajpai, V. K., Kamle, M., Shukla, S., Mahato, D. K., Chandra, P., Hwang, S. K., \& Han, Y. K. (2018). Prospects of using nanotechnology for food preservation, safety, and security. Journal of Food and Drug Analysis, 26(4), 1201-1214.

Banterle, A., Ricci, E. C., \& Cavaliere, A. (2018). Environmental sustainability and the food system. Regulating and managing food safety in the EU (pp. 57-88). Cham: Springer.

Barile, S., \& Polese, F. (2010). Smart service systems and viable service systems: Applying systems theory to service science. Service Science, 2(1-2), 21-40.

Barile, S., Carrubbo, L., Iandolo, F., \& Caputo, F. (2013). From'EGO'to'ECO'in B2B relationships. Journal of Business Market Management, 6(4), 228-253.

Barile, S., Saviano, M., Iandolo, F., \& Calabrese, M. (2014). The viable systems approach and its contribution to the analysis of sustainable business behaviors. Systems Research and Behavioral Science, 31(6), 683-695.

Barrett, C. B., Bachke, M. E., Bellemare, M. F., Michelson, H. C., Narayanan, S., \& Walker, T. F. (2012). Smallholder participation in contract farming: Comparative evidence from five countries. World Development, 40(4), 715-730.

Batista, L., Bourlakis, M., Smart, P., \& Maull, R. (2018). In search of a circular supply chain archetype-a content-analysis-based literature review. Production Planning \& Control, 29(6), 438-451.

Béné, C., Oosterveer, P., Lamotte, L., Brouwer, I. D., de Haan, S., Prager, S. D., Talsma, E. F., \& Khoury, C. K. (2019). When food systems meet sustainability - Current narratives and implications for actions, World Development, 113, 116-130.

Borrello, M., Caracciolo, F., Lombardi, A., Pascucci, S., \& Cembalo, L. (2017). Consumers' perspective on circular economy strategy for reducing food waste. Sustainability, 9(1), 141.

Borrello, M., Lombardi, A., Pascucci, S., \& Cembalo, L. (2016). The seven challenges for transitioning into a bio-based circular economy in the agri-food sector. Recent Patents on Food, Nutrition \& Agriculture, 8(1), 39-47.

Brennan, G., Tennant, M., \& Blomsma, F. (2015). Business and production solutions: Closing loops and the circular economy. Sustainability (pp. 219-239). London: Routledge.

Buch-Hansen, H. (2018). The prerequisites for a degrowth paradigm shift: Insights from critical political economy. Ecological Economics, 146, 157-163.

Cappelli, A., \& Cini, E. (2021). Challenges and opportunities in wheat flour, pasta, bread, and bakery product production chains: A systematic review of innovations and improvement strategies to increase sustainability, productivity, and product quality. Sustainability, 13(5), 2608.

Cappelli, A., Oliva, N., \& Cini, E. (2020). Stone milling versus roller milling: A systematic review of the effects on wheat flour quality, dough rheology, and bread characteristics. Trends in Food Science \& Technology, 97, 147-155.

Carbone, M., Donia, D. T., Sabbatella, G., \& Antiochia, R. (2016). Silver nanoparticles in polymeric matrices for fresh food packaging. Journal of King Saud University-Science, 28(4), 273-279.

Caron, P., Ferrero y de Loma-Osorio, G., Nabarro, D., et al. (2018). Food systems for sustainable development: proposals for a profound four-part transformation. Agronomy for Sustainable Development, 38,41 .

Cassman, K. G. (1999). Ecological intensification of cereal production systems: Yield potential, soil quality, and precision agriculture. Proceedings of the National Academy of Sciences, 96(11), 5952-5959.

Chalak, A., Abou-Daher, C., Chaaban, J., \& Abiad, M. G. (2016). The global economic and regulatory determinants of household food waste generation: A cross-country analysis. Waste Management, $48,418-422$.

Chen, J. (2017). Breaking Down Barriers to Digital Government: How can we enable vulnerable consumers to have equal participation in digital government?. Sydney: Australian Communications Consumer Action Network.

Cicatiello, C., Franco, S., Pancino, B., \& Blasi, E. (2016). The value of food waste: An exploratory study on retailing. Journal of Retailing and Consumer Services, 30, 96-104.

Cimini, A., \& Moresi, M. (2019). A progressive approach towards a more sustainable food industry. Chemical Engineering, 75, 125-146. 
Clark, J. H., Luque, R., \& Matharu, A. S. (2012). Green chemistry, biofuels, and biorefinery. Annual Review of Chemical Biomolecular, 3, 183-207.

COM. (2013). Report from the commission to the european parliament and the council on the case for a local farming and direct sales labeling scheme. http://ec.europa.eu/agriculture/quality/loca-farmi ng-direct-sales/pdf/com-report-12-2013_en.pdf. Accessed Aug 2019.

De Angelis, R., Howard, M., \& Miemczyk, J. (2018). Supply chain management and the circular economy: Towards the circular supply chain. Production Planning \& Control, 29(6), 425-437.

Duncan, T. V. (2011). Applications of nanotechnology in food packaging and food safety: Barrier materials, antimicrobials and sensors. Journal of Colloid and Interface Science, 363(1), 1-24.

Duru, M., Thérond, O., \& Fares, M. (2015). Designing agroecological transitions. Agronomy for Sustainable Development, 35, 1237-1257.

El Bilali, H., Callenius, C., Strassner, C., \& Probst, L. (2019). Food and nutrition security and sustainability transitions in food systems. Food and Energy Security, 8(2), 154.

Ellen MacArthur Foundation. (2013). Towards the circular economy: An economic and business rationale for an accelerated transition. Cowes: Ellen MacArthur Foundation.

Elia, V., Gnoni, M. G., \& Tornese, F. (2017). Measuring circular economy strategies through index methods: A critical analysis, Journal of Cleaner Production, 142(4), 2741-2751.

EMF (Ellen MacArthur Foundation), 2012. Towards the Circular Economy. https://www.ellenmacarthurf oundation.org/publications/towards-the-circulareconomy-vol-1-an-economic-and-businessrationa le-for-an-accelerated-transition.

EMF (Ellen MacArthur Foundation), 2014. Towards the Circular Economy: Accelerating the Scale-Up across Global Supply Chains. http://www3.weforum.or/docs/WEF_ENV_TowardsCircularEcono my_Report_2014.pdf.

Ene, S., \& Öztürk, N. (2014). Open loop reverse supply chain network design. Procedia-Social and Behavioral Sciences, 109, 1110-1115.

Evans, D. (2011). Thrifty, green or frugal: reflections on sustainable consumption in a changing economic climate. Geoforum, 42, 550-557.

Faggini, M., Cosimato, S., Nota, F. D., \& Nota, G. (2019). Pursuing sustainability for healthcare through digital platforms. Sustainability, 11(1), 165.

FAO. (2013). Food wastage footprint: impacts on natural resources. Rome: Food and Agricultural Organization.

FAO. (2014). The State of Food Insecurity in the World 2013. Rome: Food and Agriculture Orginization of the United Nations.

Farooque, M., Zhang, A., Thurer, M., Qu, T., \& Huisingh, D. (2019). Circular supply chain management: A definition and structured literature review. Journal of Cleaner Production, 228, 882-900.

Fattibene, D., \& Bianchi M., (2017), Fighting against Food Losses and Waste: An EU Agenda, IAM Working papers, 17, June 2017.

Food, I. P. E. S. (2015). The new science of sustainable food systems. Overcoming barriers to food system reform. IPES Food, Brussels.

Foti, V. T., Sturiale, L., \& Timpanaro, G. (2018). An overview of food waste phenomenon: By problem to resource. Calitatea, 19(S1), 232-240.

Gaitán-Cremaschi, D., Klerkx, L., Duncan, J., Trienekens, J. H., Huenchuleo, C., Dogliotti, S., \& Rossing, W. A. (2019). Characterizing diversity of food systems in view of sustainability transitions. A review. Agronomy for Sustainable Development, 39(1), 1.

Gaitán-Cremaschi, D., Klerkx, L., Duncan, J., Trienekens, J. H., Huenchuleo, C., Dogliotti, S., \& Rossing, W. A. (2020). Sustainability transition pathways through ecological intensification: An assessment of vegetable food systems in Chile. International Journal of Agricultural Sustainability, $18(2), 131-150$.

Galli, A., Iha, K., Halle, M., El Bilali, H., Grunewald, N., Eaton, D., \& Bottalico, F. (2017). Mediterranean countries' food consumption and sourcing patterns: An ecological footprint viewpoint. Science of the Total Environment, 578, 383-391.

Galli, F., Bartolini, F., Brunori, G., Colombo, L., Gava, O., Grando, S., \& Marescotti, A. (2015). Sustainability assessment of food supply chains: An application to local and global bread in Italy. Agricultural and Food Economics, 3(1), 21.

Garcia-Garcia, G., Woolley, E., Rahimifard, S., Colwill, J., White, R., \& Needham, L. (2017). A methodology for sustainable management of food waste. Waste and Biomass Valorization, 8(6), 2209-2227. 
Garrone, P., Melacini, M., \& Perego, A. (2014). Opening the black box of food waste reduction. Food Policy, 46, 129-139.

Gaustad, G., Krystofik, M., Bustamante, M., \& Badami, K. (2018). Circular economy strategies for mitigating critical material supply issues. Resources, Conservation and Recycling, 135, 24-33.

Gebbers, R., \& Adamchuk, V. I. (2010). Precision agriculture and food security. Science, 327(5967), $828-831$.

Geels, F. W. (2005). The dynamics of transitions in socio-technical systems: A multi-level analysis of the transition pathway from horse-drawn carriages to automobiles (1860-1930). Technology Analysis \& Strategic Management, 17(4), 445-476.

Geels, F. W., Kern, F., Fuchs, G., Hinderer, N., Kungl, G., Mylan, J., \& Wassermann, S. (2016). The enactment of socio-technical transition pathways: A reformulated typology and a comparative multi-level analysis of the German and UK low-carbon electricity transitions (1990-2014). Research Policy, 45(4), 896-913.

Genovese, A., Acquaye, A. A., Figueroa, A., \& Koh, S. L. (2017). Sustainable supply chain management and the transition towards a circular economy: Evidence and some applications. Omega, 66, 344-357.

Ghisellini, P., Cialani, C., \& Ulgiati, S. (2016). A review on circular economy: The expected transition to a balanced interplay of environmental and economic systems. Journal of Cleaner Production, 2016(114), 11-32.

Giampietro, M. (2019). On the circular bioeconomy and decoupling: Implications for sustainable growth. Ecological Economics, 162, 143-156.

Giampietro, M., \& Funtowicz, S. O. (2020). From elite folk science to the policy legend of the circular economy. Environmental Science \& Policy, 109, 64-72.

Glazko, V. I., \& Kosovski, G. Y. (2018). Globalization and agrarian civilization. Advances in Social Sciences Research Journal, 5(2), 56-78.

Gondchawar, N., \& Kawitkar, R. S. (2016). IoT based smart agriculture. International Journal of Advanced Research in Computer and Communication Engineering, 5(6), 838-842.

González-Rodríguez, M. R., Díaz-Fernández, M. C., \& Simonetti, B. (2015). The social, economic and environmental dimensions of corporate social responsibility: The role played by consumers and potential entrepreneurs. International Business Review, 24(5), 836-848.

Goodman, D., DuPuis, E. M., \& Goodman, M. K. (2012). Alternative food networks: Knowledge, practice, and politics. Routledge.

Grin, J., Rotmans, J., \& Schot, J. (2010). Transitions to sustainable development: New directions in the study of long term transformative change. Routledge.

Gustavsson, J., Cederberg, C., Sonesson, U., van Otterdijk, R., \& Meybeck, A. (2011). Global food losses and food waste-extent, causes and prevention. FAO.

Haas, W., Krausmann, F., Wiedenhofer, D., \& Heinz, M. (2015). How circular is the global economy?: An assessment of material flows, waste production, and recycling in the European Union and the world in 2005. Journal of Industrial Ecology, 19(5), 765-777.

Hanson, C., Lipinski, B., Robertson, K., Dias, D., Gavilan, I., Gréverath, P., et al. (2016). Food Loss and Waste Accounting and Reporting Standard. WRI, Nestlé, CGF, FAO, EU-funded FUSIONS project, UNEP, WRAP, WBCSD, NRI.

He, X., \& Hwang, H. M. (2016). Nanotechnology in food science: Functionality, applicability, and safety assessment. Journal of Food and Drug Analysis, 24(4), 671-681.

Hoseinnejad, M., Jafari, S. M., \& Katouzian, I. (2018). Inorganic and metal nanoparticles and their antimicrobial activity in food packaging applications. Critical Reviews in Microbiology, 44(2), $161-181$.

Howard, M., Hopkinson, P., \& Miemczyk, J. (2019). The regenerative supply chain: A framework for developing circular economy indicators. International Journal of Production Research, 57(23), $7300-7318$.

https://www.theconsumergoodsforum.com/initiatives/environmentalsustainability/key-projects/ food-solid-waste

IFPRI. (2016). Global Nutrition Report 2016: From promise to impact: Ending malnutrition by 2030. Retrieved from Washington, DC

IPES (2016), From uniformity to diversity: a paradigm shift from industrial agriculture to diversified agroecological systems. International Panel of Experts on Sustainable Food systems.

IPO, International Pasta Organization (IPO). (2014). The World Pasta Industry Status Report 2014; International Pasta Organization (IPO): Rome, Italy 
Jacquet, J. L., \& Pauly, D. (2007). The rise of seafood awareness campaigns in an era of collapsing fisheries. Marine Policy, 31(3), 308-313.

Jagau, H. L., \& Vyrastekova, J. (2017). Behavioral approach to food waste: An experiment. British Food Journal, 119(4), 882-894.

Jedermann, R., Nicometo, M., Uysal, I., \& Lang, W. (2014). Reducing food losses by intelligent food logistics. Philosophical Transactions of the Royal Society of London Series A, 372, 20130302-20130302.

Jellil, A., Woolley, E., \& Rahimifard, S. (2018). Towards integrating production and consumption to reduce consumer food waste in developed countries. International Journal of Sustainable Engineering, 11(5), 294-306.

Jurgilevich, A., Birge, T., Kentala-Lehtonen, J., Korhonen-Kurki, K., Pietikäinen, J., Saikku, L., \& Schösler, H. (2016). Transition towards circular economy in the food system. Sustainability, 8(1), 69.

Kalmykova, Y., Sadagopan, M., \& Rosado, L. (2018). Circular economy - From review of theories and practices to development of implementation tools. Resources, Conservation and Recycling, 135, 190-201.

Kenné, J. P., Dejax, P., \& Gharbi, A. (2012). Production planning of a hybrid manufacturing-remanufacturing system under uncertainty within a closed-loop supply chain. International Journal of Production Economics, 135(1), 81-93.

Kirtil, E., Cikrikci, S., McCarthy, M. J., \& Oztop, M. H. (2017). Recent advances in time domain NMR \& MRI sensors and their food applications. Current Opinion in Food Science, 17, 9-15.

Kravchenko, M., Pigosso, D. C., \& McAloone, T. C. (2019). Towards the ex-ante sustainability screening of circular economy initiatives in manufacturing companies: Consolidation of leading sustainability-related performance indicators. Journal of Cleaner Production, 241, 118318.

Kuokkanen, A., Nurmi, A., Mikkilä, M., Kuisma, M., Kahiluoto, H., \& Linnanen, L. (2018). Agency in regime destabilization through the selection environment: The Finnish food system's sustainability transition. Research Policy, 47(8), 1513-1522.

Lamine, C., \& Dawson, J. (2018). The agroecology of food systems: Reconnecting agriculture, food, and the environment. Agroecology and Sustainable Food Systems, 42(6), 629-636.

Last Minute Market, S. W. G. (2016). Waste watcher 2016 report.

Lin, C. S. K., Pfaltzgraff, L. A., Herrero-Davila, L., Mubofu, E. B., Abderrahim, S., Clark, J. H., Koutinas, A. A., Kopsahelis, N., Stamatelatou, K., \& Dickson, F. (2013). Food waste as a valuable resource for the production of chemicals, materials and fuels. Current situation and global perspective. Energy Environmental Science, 6, 426-464.

Lipper, L., Thornton, P., Campbell, B. M., Baedeker, T., Braimoh, A., Bwalya, M., \& Hottle, R. (2014). Climate-smart agriculture for food security. Nature Climate Change, 4(12), 1068.

Lipinski, B., Hanson, C., Lomax, J., Kitinoja, L., Waite, R., \& Searchinger, T. (2013). Reducing Food Loss and Waste. Working Paper, Installment 2 of Creating a Sustainable Food Future. Washington, DC: World Resources Institute.

Liu, Z., Adams, M., \& Walker, T. R. (2018). Are exports of recyclables from developed to developing countries waste pollution transfer or part of the global circular economy? Resources, Conservation and Recycling, 136, 22-23.

Luederitz, C., Abson, D. J., Audet, R., \& Lang, D. J. (2017). Many pathways toward sustainability: Not conflict but co-learning between transition narratives. Sustainability Science, 12, 393-407.

Mahlein, A. K. (2016). Plant disease detection by imaging sensors-parallels and specific demands for precision agriculture and plant phenotyping. Plant Disease, 100(2), 241-251.

Menozzi, D., Fioravanzi, M., \& Donati, M. (2015). Farmer's motivation to adopt sustainable agricultural practices. Bio-Based and Applied Economics Journal, 4(1), 125-147.

Mihai, F. C., \& Ingrao, C. (2018). Assessment of biowaste losses through unsound waste management practices in rural areas and the role of home composting. Journal of Cleaner Production, 172, 1631-1638.

Mogili, U. R., \& Deepak, B. B. V. L. (2018). Review on application of drone systems in precision agriculture. Procedia Computer Science, 133, 502-509.

Mondéjar-Jiménez, J. A., Ferrari, G., Secondi, L., \& Principato, L. (2016). From the table to waste: An exploratory study on behaviour towards food waste of Spanish and Italian youths. Journal of Cleaner Production, 138, 8-18.

Murray, A., Skene, K., \& Haynes, K. (2017). The circular economy: An interdisciplinary exploration of the concept and application in a global context. Journal of Business Ethics, 140(3), 369-380. 
Murugan, D., Garg, A., \& Singh, D. (2017). Development of an adaptive approach for precision agriculture monitoring with drone and satellite data. IEEE Journal of Selected Topics in Applied Earth Observations and Remote Sensing, 10(12), 5322-5328.

Nasir, A., Toor, M. S., \& Vatta, K. (2014). Composite Index for Measuring Sustainability of Food Systems in Punjab. Current Science, 106, 170-175.

National Research Council Policy Division Board on Sustainable Development. (1999). Our common journey: A transition toward sustainability. Natl Acad Press.

Nocella, G., \& Kennedy, O. (2012). Food health claims-what consumers understand. Food Policy, 37(5), 571-580.

Patil, K. A., \& Kale, N. R. (2016). A model for smart agriculture using IoT. In 2016 international conference on global trends in signal processing, information computing and communication (ICGTSPICC) (pp. 543-545). IEEE.

Priefer, C., Jörissen, J., \& Bräutigam, K. R. (2016). Food waste prevention in Europe-A cause-driven approach to identify the most relevant leverage points for action. Resources, Conservation and Recycling, 109, 155-165.

Principato, L., Ruini, L., Guidi, M., \& Secondi, L. (2019). Adopting the circular economy approach on food loss and waste: The case of Italian pasta production. Resources, Conservation and Recycling, 144, 82-89.

Principato, L., Secondi, L., \& Pratesi, C. A. (2015). Reducing food waste: An investigation on the behaviour of Italian youths. British Food Journal, 117(2), 731-748.

Recchia, L., Cappelli, A., Cini, E., Garbati Pegna, F., \& Boncinelli, P. (2019). Environmental sustainability of pasta production chains: An integrated approach for comparing local and global chains. Resources, 8(1), 56.

Rees, W. E. (2020). Ecological economics for humanity's plague phase. Ecological Economics, 169, 106519.

Ricci, E. C., Peri, M., \& Baldi, L. (2019). The Effects of Agricultural Price Instability on Vertical Price Transmission: A Study of the Wheat Chain in Italy. Agriculture, 9(2), 36.

Richards, T. J., \& Hamilton, S. F. (2018). Food waste in the sharing economy. Food Policy, 75, $109-123$.

Rueda, X., Garrett, R. D., \& Lambin, E. F. (2017). Corporate investments in supply chain sustainability: Selecting instruments in the agri-food industry. Journal of Cleaner Production, 142, 2480-2492.

San Martin, D., Ramos, S., \& Zufía, J. (2016). Valorisation of food waste to produce new raw materials for animal feed. Food Chemistry, 198, 68-74.

Saviano, M., Barile, S., Farioli, F., \& Orecchini, F. (2019). Strengthening the science-policy-industry interface for progressing toward sustainability: a systems thinking view. Sustainability Science, 14, $1-16$.

Schösler, H., De Boer, J., \& Boersema, J. J. (2012). Can we cut out the meat of the dish? Constructing consumer-oriented pathways towards meat substitution. Appetite, 58(1), 39-47.

Schösler, H., de Boer, J., Boersema, J. J., \& Aiking, H. (2015). Meat and masculinity among young Chinese, Turkish and Dutch adults in the Netherlands. Appetite, 89, 152-159.

Schott, A. B. S., Wenzel, H., \& la Cour Jansen, J. (2016). Identification of decisive factors for greenhouse gas emissions in comparative life cycle assessments of food waste management-an analytical review. Journal of Cleaner Production, 119, 13-24.

Searchinger, T., Waite, R., Hanson, C., Ranganathan, J., \& Ranganathan, E., (2019). Creating a Sustainable Food Future - a Menu of Solutions to Feed Nearly 10 Billion People by 2050 (Final Report), WRI.

Secondi, L., Principato, L., Ruini, L., \& Guidi, M. (2019). Reusing food waste in food manufacturing companies: The case of the tomato-sauce supply Chain. Sustainability, 11(7), 2154.

Seuring, S., \& Müller, M. (2008). From a literature review to a conceptual framework for sustainable supply chain management. Journal of Cleaner Production, 16(15), 1699-1710.

Shafiee-Jood, M., \& Cai, X. (2016). Reducing food loss and waste to enhance food security and environmental sustainability. Environmental Science \& Technology, 50(16), 8432-8443.

Shmelev, S. (Ed.). (2016). Green economy reader: Lectures in ecological economics and sustainability (Vol. 6). Berlin: Springer.

Shove, E. (2014). Putting practice into policy: Reconfiguring questions of consumption and climate change. Contemporary Social Science, 9(4), 415. 
Smith, J., Andersson, G., Gourlay, R., Karner, S., Mikkelsen, B. E., Sonnino, R., \& Barling, D. (2016). Balancing competing policy demands: The case of sustainable public sector food procurement. Journal of Cleaner Production, 112, 249-256.

Sonnino, R., \& Coulson, H. (2021). Unpacking the new urban food agenda: The changing dynamics of global governance in the urban age. Urban Studies, 58(5), 1032-1049.

Sorman, A. H., \& Giampietro, M. (2013). The energetic metabolism of societies and the degrowth paradigm: Analyzing biophysical constraints and realities. Journal of Cleaner Production, 38, 80.

Sousa-Zomer, T. T., Magalhães, L., Zancul, E., Campos, L. M., \& Cauchick-Miguel, P. A. (2018). Cleaner production as an antecedent for circular economy paradigm shift at the micro-level: Evidence from a home appliance manufacturer. Journal of Cleaner Production, 185, 740-748.

Spohrer, J., Maglio, P. P., Bailey, J., \& Gruhl, D. (2007). Steps toward a science of service systems. Computer, 40(1), 71-77.

Taylor, M. (2018). Climate-smart agriculture: What is it good for? The Journal of Peasant Studies, 45(1), 89-107.

Toldrá, F., Aristoy, M. C., Mora, L., \& Reig, M. (2012). Innovations in value-addition of edible meat byproducts. Meat Science, 92, 290-296.

Tukker, A. (2015). Product services for a resource-efficient and circular economy-a review. Journal of Cleaner Production, 97, 76-91.

UNAFPA (Union de Associations de Fabricants de Pâtes Alimentaires). (2015). Statistics—world pasta production. Accessed July, 2019. http://www.pasta-unafpa.org/ingstatistics5.htm

UNAFPA (Union de Associations de Fabricants de Pâtes Alimentaires). (2018). Product environmental footprint category rules (PEFCR) for dry pasta. Vers. 3. Accessed July, 2019 http://ec.europa.eu/ environment/eussd/smgp/pdf/Dry\%20pasta\%20PEFCR_final.pdf

UNEP. (2014). Prevention and reduction of food and drink waste in businesses and households - Guidance for governments, local authorities, businesses and other organisations, Version 1.0.

United Nations General Assembly. (2015). Transforming our world: The 2030 agenda for sustainable development. New York: Division for Sustainable Development Goals.

Valenti, W. C., Kimpara, J. M., Preto, B. D. L., \& Moraes-Valenti, P. (2018). Indicators of sustainability to assess aquaculture systems. Ecological Indicators, 88, 402-413.

Webster, K. (2015). The Circular Economy: a Wealth of Flows, Ellen MacArthur Foundation, Isle of Wight.

Weetman, C. (2016). A circular economy handbook for business and supply chains: Repair, remake, redesign, rethink. Kogan Page Publishers.

WHO (World Health Organization). (2015). Global platform for food safety data and information. Accessed July, 2019 http://www.who.int/foodsafety/foscollab_dashboards/en

Winans, K., Kendall, A., \& Deng, H. (2017). The history and current applications of the circular economy concept. Renewable and Sustainable Energy Reviews, 68, 825-833.

Woolley, E., Garcia-Garcia, G., Tseng, R., \& Rahimifard, S. (2016). Manufacturing resilience via inventory management for domestic food waste. Procedia CIRP, 40, 372-377.

WRAP (2013). Household food and drink waste in the United Kingdom 2012. Accessed July, 2019 http:// www.wrap.org.uk/sites/files/wrap/hhfdw-2012-main.pdf.pdf/

WRAP. (2014). Food connection programme. Final report, WRAP: Banbury. Accessed Jun, 2019 http:// www.wrap.org.uk/sites/files/wrap/Food\%20Connection\%20Programme\%20Final\%20Published\% 20Report.pdf

WRAP. (2017). Household food waste in the UK, 2015. Accessed June, 2019. http://www.wrap.org.uk/ sites/files/wrap/Household_food_waste_in_the_UK_2015_Report.pdf

Youssef, A. M., \& El-Sayed, S. M. (2018). Bionanocomposites materials for food packaging applications: Concepts and future outlook. Carbohydrate Polymers, 193, 19-27.

Publisher's Note Springer Nature remains neutral with regard to jurisdictional claims in published maps and institutional affiliations. 


\section{Authors and Affiliations}

\section{Marisa Faggini $^{1}\left(\mathbb{D} \cdot\right.$ Silvia Cosimato $^{2} \cdot$ Anna Parziale $^{3}$}

Silvia Cosimato

silvia.cosimato@unina.it

Anna Parziale

aparziale@unisa.it

1 Department of Economics and Statistics, University of Salerno, Via Giovanni Paolo II, 84084 Fisciano, Italy

2 Department of Economics, Management, Institutions, University of Naples Federico II, Napoli, Italy

3 Department of Law Sciences, University of Salerno, Via Giovanni Paolo II, 84084 Fisciano, Italy 